\title{
Lolium rigidum Gaud. biotypes from Greece with Resistance to Glyphosate and other Herbicides
}

\author{
Ilias TRAVLOS ${ }^{1 *}$, Ioanna TABAXI ${ }^{1}$, Dimitrios PAPADIMITRIOU ${ }^{1}$, Dimitrios BILALIS ${ }^{1}$ and Demosthenis \\ CHACHALIS ${ }^{2}$ \\ ${ }^{1}$ Faculty of Crop Science, Laboratory of Agronomy, Agricultural University of Athens, Greece. \\ ${ }^{2}$ Laboratory of Weed Science, Benaki Phytopathological Institute. \\ *)Corresponding author, e-mail: htravlos@yahoo.gr \\ BulletinUASVM Horticulture 73(1) / 2016 \\ Print ISSN 1843-5254, Electronic ISSN 1843-5394 \\ DOI:10.15835/buasvmcn-hort:11772
}

\begin{abstract}
Monoculture and extensive use of glyphosate, ACCase and ALS inhibitors can greatly increase the risks of reduced efficacy of these herbicides on several weeds. In our study, seed samples of five Lolium rigidum accessions were collected from wheat fields and olive orchards in 2012 and 2013. Most of the sites were known as having poor L. rigidum control and pot experiments were conducted in order to evaluate the sensitivity of the biotypes to glyphosate, clodinafop and chlorsulfuron. Data analysis confirmed significant differences in biomass reduction of the several biotypes in response to the herbicides. In particular, one biotype was found to be resistant to glyphosate, one to clodinafop and two to chlorsulfuron, while several biotypes had an intermediate response. These findings confirm that the reported unsatisfactory control of rigid ryegrass could be attributed to herbicide resistance and therefore rotational use of herbicides and several non-chemical methods are required.
\end{abstract}

Keywords: Lolium rigidum, glyphosate, herbicide resistance

\section{INTRODUCTION}

Resistance to herbicides such as glyphosate, ACCase and ALS inhibitors is globally a serious problem (Travlos and Chachalis, 2010; Travlos et al., 2011). Herbicide resistance is a serious That is the reality in all Mediterranean countries including Greece, with frequent reports of low efficacy of the previously mentioned herbicides against increasingly problematic weeds, such as Conyza spp. or Lolium spp. (Walsh et al., 2011; González-Torralva et al., 2012).

Lolium includes several species such as $L$. rigidum (rigid ryegrass), L. perenne (perennial ryegrass) and $L$. multiflorum (Italian ryegrass). Among them, rigid ryegrass is very abundant in winter cereals, orchards, vineyards, alfalfa and non-arable lands. Furthermore, it is regarded to be one of the most important weeds in terms of developing resistance to multiple herbicides due to the high levels of genetic diversity (Tranel and Trucco, 2009).
Taking into account the several reports of inadequate chemical control of Lolium spp. across Greece, the aim of this study is to evaluate the resistance of ryegrass ( $L$. rigidum) accessions collected from winter cereals and perennial crops to glyphosate, clodinafop and chlorsulfuron.

\section{MATERIALS AND METHODS}

Mature seed samples of five L. rigidum accessions were collected from wheat fields and olive orchards in 2012 and 2013. Most of the sites were known as having poor L. rigidum control, while an accession from an olive grove never treated with herbicides was used as our reference susceptible. Moreover, a biotype of confirmed resistance to glyphosate (R1) was also included in our study (De Prado, personal communication). Plants were grown in $1 \mathrm{~L}$ pots $(12 \mathrm{~cm}$ diameter) containing perlite and soil (1:2 by volume) and watered as required. When seedlings were at 3-5 leaves stage, they were sprayed with the maximum 

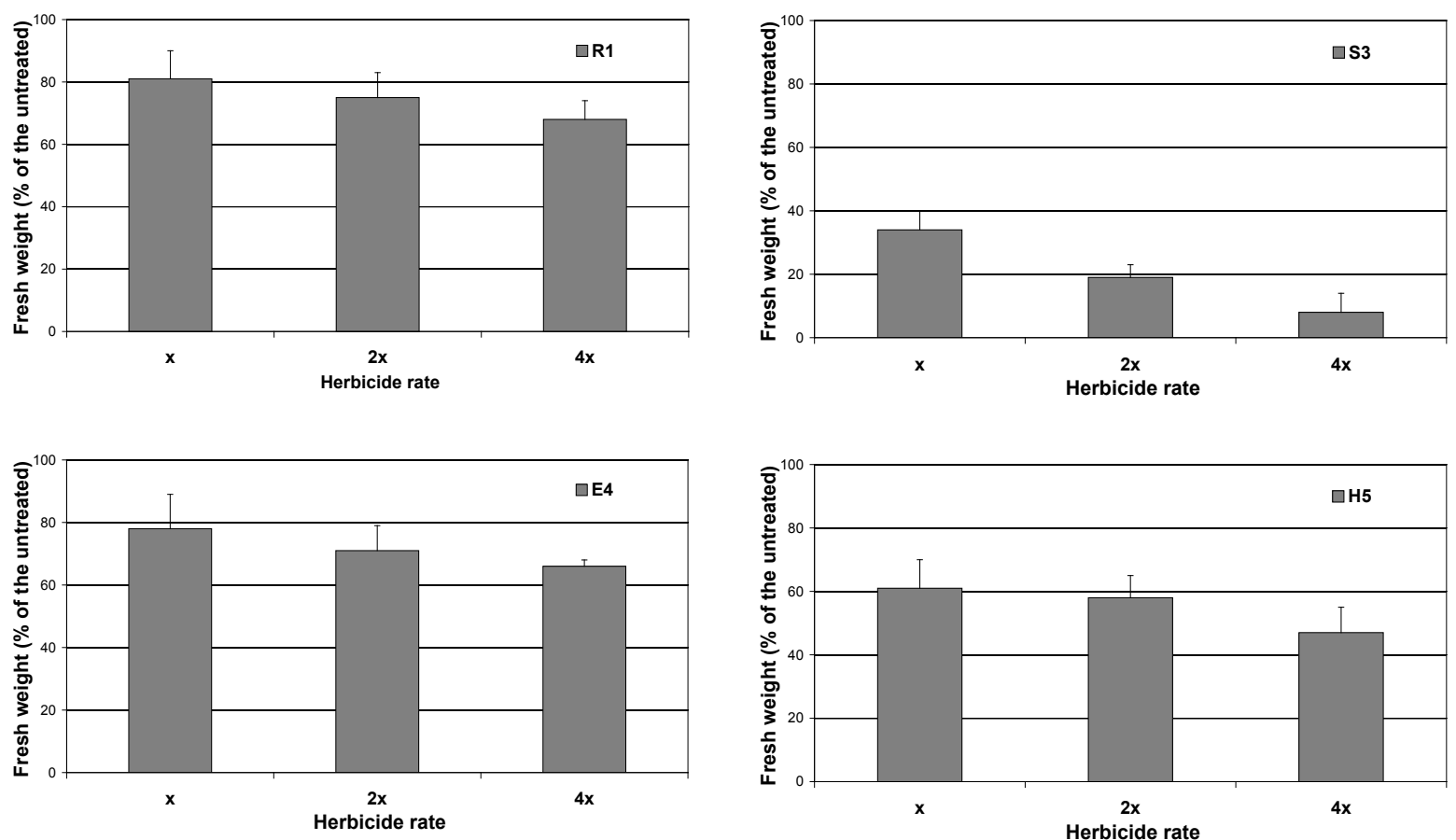

Fig.1. Response of several L. rigidum biotypes to glyphosate

recommended rates (and also two and four times the recommended rates) of the above-mentioned herbicides using a low pressure flat-fan nozzle sprayer delivering herbicide in $300 \mathrm{~L} / \mathrm{h}$ a water at $250 \mathrm{kPa}$. Fresh weight reduction was used as an indication of the herbicide resistance according to the rating system proposed by Moss et al. (1999).

\section{RESULTS AND DISCUSSION}

Data analysis confirmed significant differences in biomass reduction of the several biotypes in response to glyphosate, clodinafop propargyl and chlorsulfuron. In Fig.1 such differences are shown. It has to be noted that among the biotypes, one proved to be resistant to glyphosate and three to clodinafop, chlorsulfuron or both. These findings are in accordance with previous studies (Busi and Powles, 2009; Han et al., 2014).

\section{CONCLUSION}

Our results revealed at least one biotype resistant to glyphosate (E4), one to clodinafop (D2) and two to chlorsulfuron (M1, H5). Conclusively, in the present research work, we demonstrated that there is an emerging problem of herbicide resistance in ryegrass. This is the first report of glyphosate resistance in ryegrass in Greece, while it seems that we have an ongoing situation with many biotypes with intermediate response. Moreover, multiple resistance might cause an even bigger challenge. Consequently, the developing resistance of $L$. rigidum to the several herbicides implies the need of lower reliance to chemical control methods.

\section{REFERENCES}

1. Busi R, Powles SB (2009). Evolution of glyphosate resistance in a Lolium rigidum population by glyphosate selection at sublethal doses. Heredity 103:318-325.

2. González-Torralva F, Gil-Humanes J, Barro F, Brants I, De Prado R (2012). Target site mutation and reduced translocation are present in a glyphosate-resistant Lolium multiflorum Lam. biotype from Spain. Plant Physiology and Biochemistry 58:16-22.

3. Han H, Yu Q Vila-Aiub M, Powles SB (2014). Genetic inheritance of cytochrome P450-mediated metabolic resistance to chlorsulfuron in a multiple herbicide resistant Lolium rigidum population. Crop Protection 65:57-63.

4. Moss SR, Clarke JH, Blair AM, Culley TN, Read MA, Ryan PJ, Turner M (1999). The occurrence of herbicideresistant grass-weeds in the United Kingdom and a new system for designating resistance in screening assays. In: Proceedings of the Brighton Crop Protection Conference on Weeds, pp. 179-184.

5. Tranel PJ, Trucco F (2009). 21st-century weed science: A call for Amaranthus genomics. Pages 53-81 In: CN Stewart, ed. Weedy and invasive plant genomics. Ames, Iowa: WileyBlackwell. 
6. Travlos IS, Chachalis D (2010). Glyphosate-resistant hairy fleabane (Conyza bonariensis) is reported in Greece. Weed Technology 24:569-573.

7. Travlos IS, Giannopolitis CN, Economou G (2011). Diclofop resistance in sterile wild oat (Avena sterilis L.) in wheat fields in Greece and its management by means of other post-emergence herbicides. Crop Protection 30:14491454.

8. Walsh MJ, Fowler TM, Crowe B, Ambe T, Powles SB (2011). The potential for pyroxasulfone to selectively control resistant and susceptible rigid ryegrass (Lolium rigidum) biotypes in Australian grain crop production systems. Weed Technology 25: 30-37. 